\title{
Assessment of the impact of vibrations on the track surface from impact loads
}

\author{
Michał Jukowski ${ }^{1, *}$, Krzysztof Śledziewski ${ }^{1}$, and Mateusz Hypki ${ }^{2}$ \\ ${ }^{1}$ Lublin University of Technology, Faculty of Civil Engineering and Architecture, Department of Road and Bridges, Nadbystrzycka \\ 40, 20-618 Lublin, Poland \\ ${ }^{2}$ Lublin University of Technology, Faculty of Civil Engineering and Architecture, Civil Engineering Laboratory, Nadbystrzycka 40, \\ 20-618 Lublin, Poland
}

\begin{abstract}
Dynamic development of the linear infrastructure in Poland directly contributed to the increase in the number of engineering sites and facilities. Due to ground conditions and values of exploitation loads, in some cases bridge supports must be placed on foundation piles, the method of execution of which may cause significant dynamic impact on the structures located in the close vicinity. The paper assesses the impact of dynamic actions resulting from impact loads during impact pile driving of FRANKA piles with the use of a guide pipe on the railway track surface, on which there is continuous railway vehicle traffic. The tests have shown that the serviceability limit condition has been met and that the construction works do not result in exceeded values of vibration acceleration.
\end{abstract}

\section{Introduction}

At the turn of the decade following Poland's accession to the European Union, a drastic development of the line infrastructure was recorded, manifesting itself mainly in the construction of many kilometres of highways and expressways. Newly designed and reconstructed sections of the road network are directly associated with engineering sites and facilities. Continuous development of the road network causes an increase in the traffic intensity of vehicles traveling on the roads, and therefore an increase in dynamic loads, which should be considered at the stage of designing bridge structures [1].

The location of the facility and soil and water conditions are important factors for the foundation of bridge supports. Nowadays, the technology of laying the foundations is so developed that the designers have full room for manoeuvre in terms of choosing how to complete them [2]. When selecting the technology of foundation setting completion, one should remember about the possibility of their negative impact on the environment. Pursuant to the Article 5 of the Construction Law Act of 7 July 1994, a building must be designed and constructed in such a way as to be protected against noise and vibration. General legal regulations concerning the protection of the environment against various impacts are included in the Environmental Protection Law Act of 27 April 2001 (Journal of Laws of 2001, No. 62, item 627, as amended) concerning the so-called environmental management. In reference to the Polish standard PN-B-06050 "Geotechnics. Earthworks. General requirements", in Section A.2. 3.4.1.17, the standard states that when geotechnical work is carried out using equipment that transmits vibrations to the ground, the impact of these vibrations on existing structures must be determined.

It should be remembered that dynamic interactions can often cause irreversible effects, causing damage to structural elements of buildings, and even lead to construction disasters in extreme cases [3,4]. The study presents a method of in situ testing of the values of accelerations (vibrations) resulting from driving FRANKA piles [5] using the impact method while maintaining the guide pipe, on the railway embankment subjected to additional dynamic load from the passage of freight and passenger trains. Basing on the tests, the authors verified the criterion of traffic safety on the railway line from the ongoing construction works and the possibility of continuous (without interruptions) movement of railway vehicles during the construction works.

\section{Measurements in situ}

\subsection{Characteristics of the tested object}

The railway embankment located in railway line No. 26 Luków - Radom at km 49+901 over the newly constructed viaduct WS-02 of the S17 expressway was analysed - Fig. 1. The embankment structure is composed of the following layers:

- Railway surface - rubble 31.5/50; compressed railway sleepers,

- Substructure of the track (embankment) - medium sand with a density of $I_{D}>0.67$ (compacted state),

- Ground substrate - clay/loamy sand, compacted (approximate information).

* Corresponding author: m.jukowski@pollub.pl 


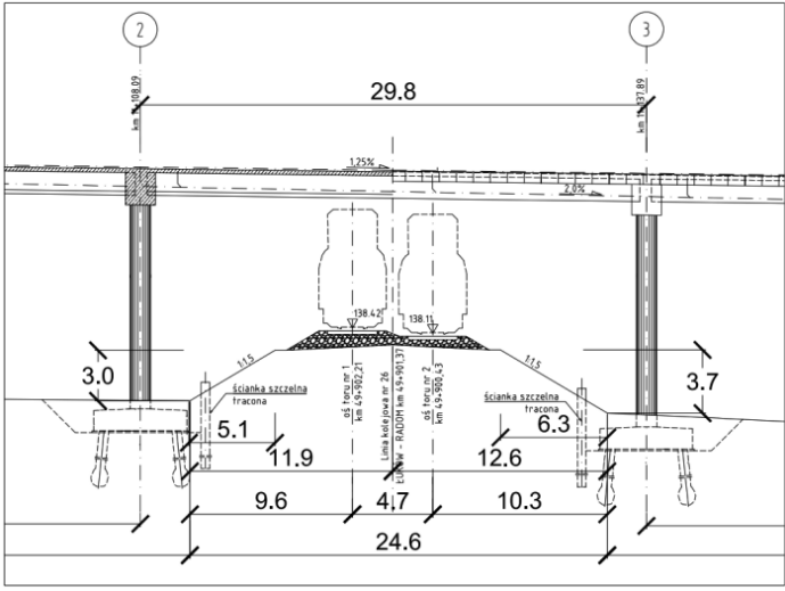

Fig. 1. Cross-section through railway embankment [6].

In addition, the railway embankment at the foot of the slope was secured with a $6.0 \mathrm{~m}$ high tight wall.

\subsection{Description of the tests}

The main objective of the dynamic tests was to determine the impact of vibrations caused by construction works involving the completion of FRANKA foundation piles in support No. $1(\mathrm{~km}$ $11+079.09)$, No. $2(\mathrm{~km} 11+108.09)$, No. $3(\mathrm{~km}$ $11+137.89)$ and No. $4(\mathrm{~km} \mathrm{11+166.89)}$ of the WS-02 site of the newly constructed S17 expressway.

In particular, the measurements concerned the effect of propagation of para-seismic vibrations from the substrate to the structure of the embankment created as a result of impact piling of foundation piles.

High-end measurement equipment was used to record the time course of the vibration acceleration of the arch structure at a sampling frequency of $6000 \mathrm{~Hz}$. During the measurements, two three-axis $(\mathrm{X}, \mathrm{Y}, \mathrm{Z})$ piezoelectric transducers, with sensitivity of $1000 \mathrm{mV} / \mathrm{g}$, were used, operating in the frequency range of $0.2-100 \mathrm{~Hz}$.

The tests were carried out at four measurement points (see Fig. 2) for each side of the embankment in accordance with the applicable regulations, i.e. the standard [7].

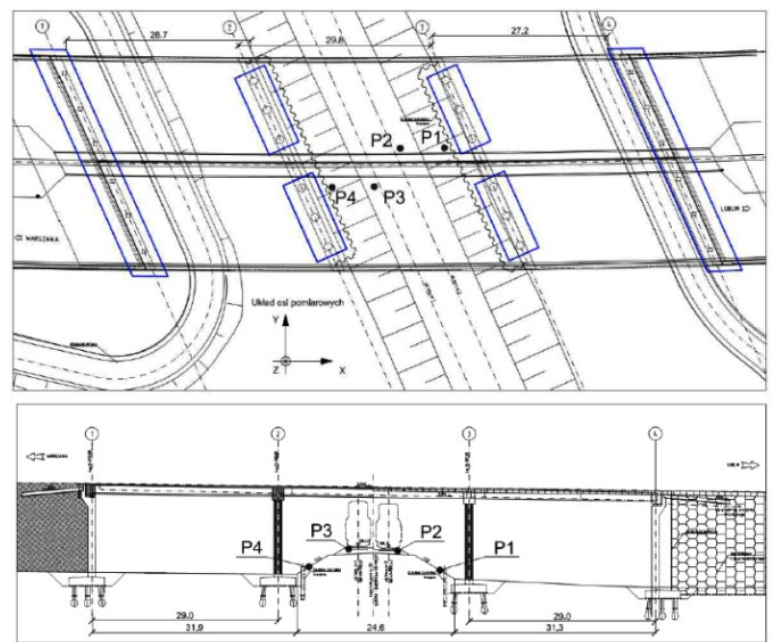

Fig. 2. Measurement point location [6].
Points P1 and P4 were located at the foot of the slope, anchored in the ground by means of specialised ground anchors, and points $\mathrm{P} 2$ and $\mathrm{P} 3$ were fixed to the compressed railway sleeper. Fig. 3 and Fig. 4 present the photos showing fixed accelerometers in $\mathrm{P} 1$ and $\mathrm{P} 2$, respectively.

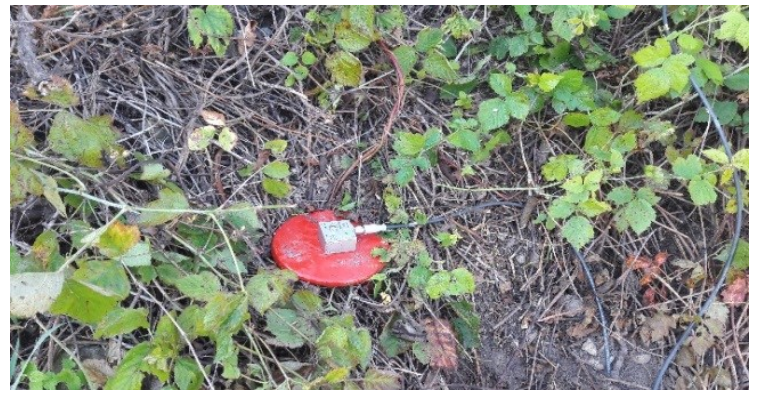

Fig. 3. Accelerometer attached to a special ground anchor measuring point $\mathrm{P} 1$.

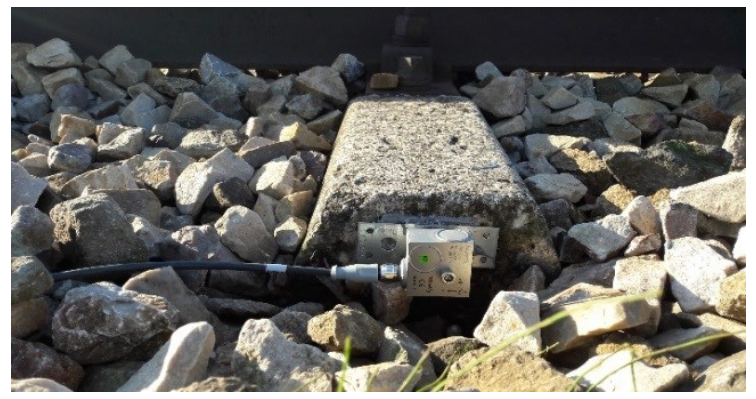

Fig. 4. Accelerometer fixed to the compressed sleeper measuring point $\mathrm{P} 2$.

The tests were carried out for each of the four supports (two intermediate supports and two end supports each). Three series of measurements were taken for each support, i.e. measurements were taken for three driven piles for each support.

The distance of the driven foundation piles from the embankment structure was:

- $\sim 28.7 \mathrm{~m}$ from the edge of the prepared pile area, support no. 1, to the foot of the embankment,

- $\sim 27.2 \mathrm{~m}$ from the edge of the prepared pile area, supports no. 4, to the foot of the embankment,

- directly at the foot of the embankment in the case of supports no. 2 and no. 3 .

Fig. 5 shows view of the pile driver located at support no. 3 .

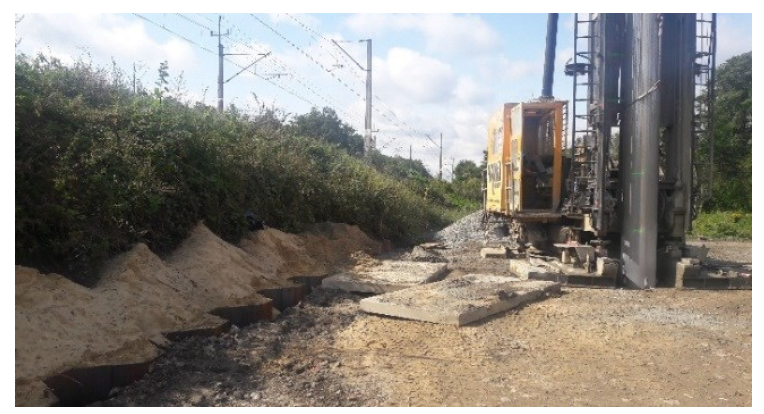

Fig. 5. Location of the pile driver in relation to the railway embankment - support no. 3 . 


\section{Analysis of measurement results}

\subsection{Results of pile driver peak accelerations}

The impact of vibrations on the track structure was assessed based on peak accelerations measured in the band up to $30 \mathrm{~Hz}[8,9]$. Vibration measurements were carried out continuously with the use of a measuring window of 10 minutes. The criterion for ensuring traffic safety is that the vertical acceleration limit of $3.5 \mathrm{~m} / \mathrm{s}^{2}$ is not exceeded.

The results of the peak acceleration values are presented in Table 1-4. Fig. 6 shows an example diagram of the acceleration amplitude versus support no. 1 time. The diagram in red shows the recorded waveform in the band up to $100 \mathrm{~Hz}$, and in black: the peak waveform in the para-seismic band up to $30 \mathrm{~Hz}$ [10].

Table 1. Max peak acceleration - support no. 1 .

\begin{tabular}{|c|c|c|c|c|c|c|c|c|}
\hline \multicolumn{9}{|c|}{ Support no. 1} \\
\hline \multirow{3}{*}{ 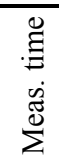 } & \multirow{3}{*}{ 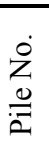 } & \multirow{3}{*}{ 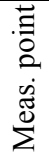 } & \multicolumn{6}{|c|}{ Peak accelerations $\left[\mathrm{m} / \mathrm{s}^{2}\right]$} \\
\hline & & & \multicolumn{3}{|c|}{$0.5-100.0 \mathrm{~Hz}$} & \multicolumn{3}{|c|}{$0.5-30.0 \mathrm{~Hz}$} \\
\hline & & & $X$ & Y & Z & $\mathrm{X}$ & Y & $\mathrm{Z}$ \\
\hline \multirow{2}{*}{$\begin{array}{l}\stackrel{8}{0} \\
\ddot{0}\end{array}$} & \multirow{2}{*}{$\stackrel{\overbrace{}}{\overbrace{}}$} & $\bar{\Xi}$ & 2.11 & 1.87 & 1.08 & 0.84 & 0.88 & 0.92 \\
\hline & & $\tilde{\tilde{n}}$ & 0.94 & 2.39 & 0.64 & 0.26 & 0.55 & 0.43 \\
\hline \multirow{2}{*}{ 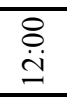 } & \multirow{2}{*}{$\stackrel{\varrho}{\rightleftarrows}$} & $\Xi$ & 3.11 & 2.31 & 1.53 & 1.04 & 1.23 & 1.28 \\
\hline & & $\tilde{n}$ & 0.93 & 3.91 & 1.55 & 0.41 & 0.59 & 1.08 \\
\hline \multirow{2}{*}{ 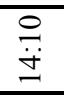 } & \multirow{2}{*}{$\stackrel{7}{=}$} & $\Xi$ & 1.78 & 1.61 & 1.38 & 0.64 & 0.99 & 1.09 \\
\hline & & $\tilde{\Omega}$ & 0.4 & 2.67 & 1.21 & 0.27 & 0.52 & 0.87 \\
\hline \multicolumn{6}{|c|}{ Maximum values } & 1.04 & 1.23 & 1.28 \\
\hline
\end{tabular}

Table 2. Max peak acceleration - support no. 2.

\begin{tabular}{|c|c|c|c|c|c|c|c|c|}
\hline \multicolumn{9}{|c|}{ Support no. 2} \\
\hline \multirow{3}{*}{ 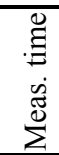 } & \multirow{3}{*}{$\begin{array}{l}\dot{z} \\
\frac{0}{2}\end{array}$} & \multirow{3}{*}{ 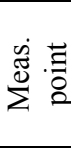 } & \multicolumn{6}{|c|}{ Peak accelerations $\left[\mathrm{m} / \mathrm{s}^{2}\right]$} \\
\hline & & & \multicolumn{3}{|c|}{$0.5-100.0 \mathrm{~Hz}$} & \multicolumn{3}{|c|}{$0.5-30.0 \mathrm{~Hz}$} \\
\hline & & & $\mathrm{X}$ & $\mathrm{Y}$ & $\mathrm{Z}$ & $\mathrm{X}$ & $\mathrm{Y}$ & $\bar{Z}$ \\
\hline \multirow{2}{*}{$\stackrel{8}{\circ}$} & \multirow{2}{*}{ స్ } & $\stackrel{ \pm}{ \pm}$ & 4.7 & 4.01 & 4.02 & 2.7 & 1.54 & $\overline{1.2}$ \\
\hline & & $\tilde{n}$ & 0.68 & 2.22 & 1.46 & 0.51 & 0.86 & 1.45 \\
\hline \multirow{2}{*}{$\stackrel{\stackrel{n}{=}}{=}$} & \multirow{2}{*}{$\underset{i}{\Delta}$} & $\frac{a}{2}$ & 1.65 & 4.56 & 2.78 & 0.81 & 2.47 & 1.62 \\
\hline & & $\tilde{\Omega}$ & 0.32 & 0.95 & 0.49 & 0.28 & 0.72 & 0.41 \\
\hline \multirow{2}{*}{ 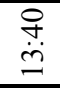 } & \multirow{2}{*}{$\stackrel{\infty}{\vec{i}}$} & \pm & 5.27 & 5.36 & 3.75 & 2.27 & 2.7 & 1.5 \\
\hline & & $\tilde{\Omega}$ & 0.62 & 2.3 & 1.46 & 0.3 & 1.22 & 1.21 \\
\hline \multicolumn{6}{|c|}{ Maximum values } & 2.7 & 2.7 & 1.62 \\
\hline
\end{tabular}

Table 3. Max peak acceleration - support no. 3 .

\begin{tabular}{|c|c|c|c|c|c|c|c|c|}
\hline \multicolumn{9}{|c|}{ Support no. 3} \\
\hline \multirow{3}{*}{ 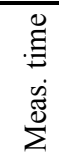 } & \multirow{3}{*}{$\begin{array}{l}\frac{2}{2} \\
\frac{0}{20}\end{array}$} & \multirow{3}{*}{ 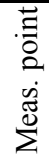 } & \multicolumn{6}{|c|}{ Peak accelerations $\left[\mathrm{m} / \mathrm{s}^{2}\right]$} \\
\hline & & & \multicolumn{3}{|c|}{$0.5-100.0 \mathrm{~Hz}$} & \multicolumn{3}{|c|}{$0.5-30.0 \mathrm{~Hz}$} \\
\hline & & & $\mathrm{X}$ & $\mathrm{Y}$ & $\mathrm{Z}$ & $\mathrm{X}$ & $\mathrm{Y}$ & Z \\
\hline \multirow{2}{*}{$\begin{array}{l}0 \\
0 \\
0\end{array}$} & \multirow{2}{*}{ i. } & $\bar{a}$ & 2.41 & 2.8 & 2.83 & 1.08 & 1.91 & 0.54 \\
\hline & & $\tilde{\Sigma}$ & 0.56 & 1.27 & 0.87 & 0.38 & 0.33 & 0.76 \\
\hline \multirow{2}{*}{$\begin{array}{l}0 \\
\stackrel{\Xi}{I} \\
\end{array}$} & \multirow{2}{*}{$\stackrel{\nabla}{m}$} & $\bar{a}$ & 4.2 & 3.26 & 3.46 & 1.48 & 1.86 & 0.59 \\
\hline & & $\bar{\Sigma}$ & 1.24 & 1.88 & 1.69 & 0.47 & 0.72 & 1.52 \\
\hline \multirow{2}{*}{$\begin{array}{l}8 \\
\dot{\varphi} \\
\end{array}$} & \multirow{2}{*}{$\underset{m}{=}$} & $\bar{E}$ & 3.66 & 2.71 & 2.83 & 0.96 & 1.17 & 0.46 \\
\hline & & $\tilde{\Sigma}$ & 0.73 & 3.07 & 2.77 & 0.29 & 1.03 & 1.92 \\
\hline \multicolumn{6}{|c|}{ Maximum values } & 1.48 & 1.91 & 1.92 \\
\hline
\end{tabular}

Table 4. Max peak acceleration - support no. 4.

\begin{tabular}{|c|c|c|c|c|c|c|c|c|}
\hline \multicolumn{9}{|c|}{ Support no. 4} \\
\hline \multirow{3}{*}{ 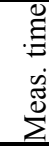 } & \multirow{3}{*}{$\begin{array}{l}\dot{\partial} \\
\frac{0}{2}\end{array}$} & \multirow{3}{*}{ 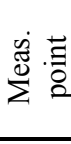 } & \multicolumn{6}{|c|}{ Peak accelerations $\left[\mathrm{m} / \mathrm{s}^{2}\right]$} \\
\hline & & & \multicolumn{3}{|c|}{$0.5-100.0 \mathrm{~Hz}$} & \multicolumn{3}{|c|}{$0.5-30.0 \mathrm{~Hz}$} \\
\hline & & & $\mathrm{X}$ & $\mathrm{Y}$ & $\mathrm{Z}$ & $\mathrm{X}$ & $\mathrm{Y}$ & Z \\
\hline \multirow{2}{*}{$\stackrel{\stackrel{\leftrightarrow}{=}}{=}$} & \multirow{2}{*}{$\stackrel{\infty}{\underset{+}{+}}$} & $\bar{a}$ & 1.46 & 0.58 & 0.96 & 1.13 & 0.18 & 0.42 \\
\hline & & $\Sigma$ & 0.34 & 0.75 & 0.82 & 0.18 & 0.4 & 0.49 \\
\hline \multirow{2}{*}{$\begin{array}{l}\stackrel{\leftrightarrow}{త} \\
\end{array}$} & \multirow{2}{*}{$\vec{\sim}$} & $\bar{a}$ & 1.19 & 0.55 & 0.73 & 1.12 & 0.25 & 0.48 \\
\hline & & $\Sigma$ & 0.2 & 0.66 & 0.66 & 0.16 & 0.46 & 0.45 \\
\hline \multirow{2}{*}{$\stackrel{\circ}{\stackrel{\oplus}{\dot{I}}}$} & \multirow{2}{*}{$\stackrel{?}{\stackrel{m}{7}}$} & $\bar{a}$ & 1.79 & 0.83 & 1.09 & 1.29 & 0.25 & 0.59 \\
\hline & & $\tilde{\Sigma}$ & 0.29 & 0.77 & 0.8 & 0.2 & 0.53 & 0.56 \\
\hline \multicolumn{6}{|c|}{ Maximum values } & 1.29 & 0.53 & $0.5 \mathrm{~s}$ \\
\hline
\end{tabular}

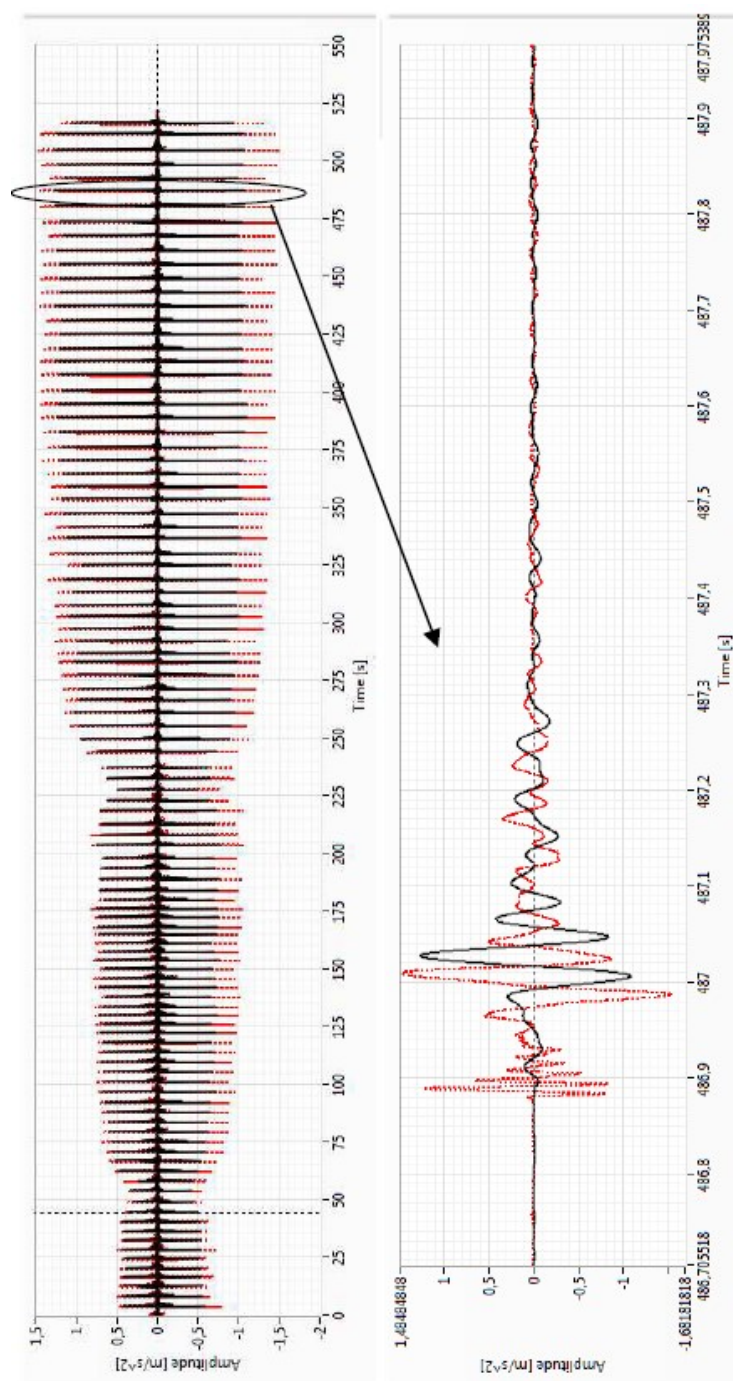

Fig. 6. Peak vibration waveform - P4 "Z" axis - sample pile 1.10 .

Basing on conducted tests, it was found that the maximum values of peak accelerations at foot of the railway embankment at points $\mathrm{P} 1$ and $\mathrm{P} 4$ amounted to $\mathrm{a}_{\mathrm{x}, \text { max,low }}=2.70 \mathrm{~m} / \mathrm{s}^{2}, \quad \mathrm{a}_{\mathrm{y}, \text { max,low }}=2.70 \mathrm{~m} / \mathrm{s}^{2}, \mathrm{a}_{\mathrm{z} \text {, max }, \text { low }}=1.92$ $\mathrm{m} / \mathrm{s}^{2}$. With reference to the values obtained with the railway sleeper at points $\mathrm{P} 2$ and $\mathrm{P} 3$, the maximum values of peak accelerations were $a_{x, \max , \text { up }}=0.51 \mathrm{~m} / \mathrm{s}^{2}$, $\mathrm{a}_{\mathrm{y}, \text { max,up }}=1.22 \mathrm{~m} / \mathrm{s}^{2}, \mathrm{a}_{\mathrm{z} \text {,max,up }}=1.45 \mathrm{~m} / \mathrm{s}^{2}$. 


\subsection{Results of peak accelerations - real train runs}

Over the course of embankment accelerations tests, train traffic on tracks No. 1 and No. 2 was carried out smoothly. Due to the construction works carried out, only the speed limit of the drafts of cars passage was introduced. During the acceleration measurements, the vibrations caused by the passing freight train were also measured.

Table 5 shows the results obtained from the passage of a real freight train in points $\mathrm{P} 3$ and $\mathrm{P} 4$ on track no. 1.

Table 5. Summary of the peak accelerations compared to the freight train passage.

\begin{tabular}{|c|c|c|c|c|c|c|c|}
\hline \multicolumn{8}{|c|}{ Freight train passage } \\
\hline \multirow{3}{*}{$\stackrel{\ddot{\Xi}}{\stackrel{\Xi}{\Sigma}}: \stackrel{\Xi}{\Xi}$} & \multirow{3}{*}{ 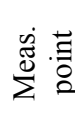 } & \multicolumn{6}{|c|}{ Peak accelerations $\left[\mathrm{m} / \mathrm{s}^{2}\right]$} \\
\hline & & \multicolumn{3}{|c|}{$0.5-100.0 \mathrm{~Hz}$} & \multicolumn{3}{|c|}{$0.5-30.0 \mathrm{~Hz}$} \\
\hline & & $X$ & $\mathrm{Y}$ & Z & X & $\mathrm{Y}$ & Z \\
\hline \multirow{2}{*}{$\stackrel{0}{\ddot{0}}$} & $\hat{\Omega}$ & 2.76 & 4.33 & 4.48 & 0.82 & 1.14 & 1.44 \\
\hline & $\stackrel{ \pm}{ \pm}$ & 0.67 & 0.91 & 1.17 & 0.26 & 0.23 & 0.39 \\
\hline
\end{tabular}

In addition, Fig. 7 and Fig. 8 show the vibration waveforms (diagram of amplitude [g] versus time [s]) also in points $\mathrm{P} 3$ and $\mathrm{P} 4$ in the recording band up to 100 $\mathrm{Hz}$.

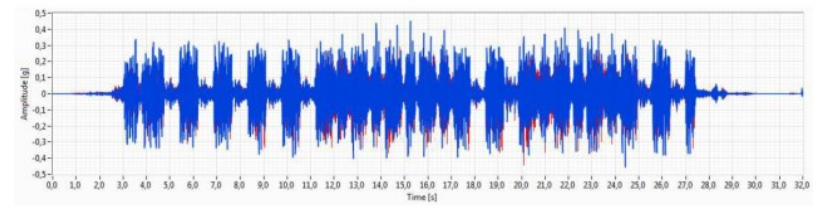

Fig. 7. Peak vibration over time $-\mathrm{P} 3$.

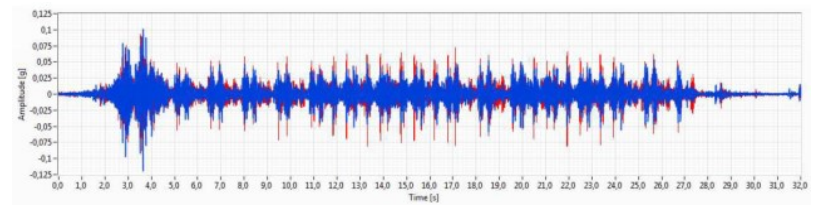

Fig. 8. Peak vibration over time $-\mathrm{P} 4$.

In order to compare the results obtained from the dynamic excitation of the passing freight train with the pile driver operation, the measured peak acceleration values are summarised in Table 6.

Table 6. Comparison of peak accelerations from the passage of the train and work related to completion of foundation piles.

\begin{tabular}{|c|c|c|c|c|c|c|}
\hline \multirow{2}{*}{$\begin{array}{c}\text { Measuring } \\
\text { point }\end{array}$} & \multicolumn{5}{|c|}{ Peak acceleration $\left[\mathrm{m} / \mathrm{s}^{2}\right]$ to $30 \mathrm{~Hz}$} \\
\cline { 2 - 7 } & \multicolumn{2}{|c|}{ Freight train passage } & \multicolumn{2}{|c|}{ Pile driver operation } \\
\cline { 2 - 7 } & $\mathrm{X}$ & $\mathrm{Y}$ & $\mathrm{Z}$ & $\mathrm{X}$ & $\mathrm{Y}$ & $\mathrm{Z}$ \\
\hline $\mathrm{P} 3$ & 0.82 & 1.14 & 1.44 & 0.47 & 1.03 & 1.92 \\
\hline $\mathrm{P} 4$ & 0.26 & 0.23 & 0.39 & 1.48 & 1.91 & 1.92 \\
\hline
\end{tabular}

Basing on the conducted tests and the obtained results, it was found that in the case of the embankment crown, the accelerations in the horizontal plane originating from a passing train are greater compared to those originating from works related to the foundation pile preparation. On the other hand, in case of vibrations in the vertical direction, accelerations of vibrations from the works related to the construction of foundation piles are greater by approx. 35\% than those created by passing train. In case of the slope foot, it was observed that vibration accelerations from construction works were more than 8 times higher than those from the train passage.

\section{Conclusions}

From the point of view of safety concerning the traffic over engineering structures and sites exposed directly to the impact of high values of accelerations (vibrations), it is necessary to verify the results obtained from the dynamic analyses carried out in terms of the vertical acceleration maximum values in accordance with [11].

The maximum acceleration values of the arch determined along each track shall not exceed $3.5 \mathrm{~m} / \mathrm{s}^{2}$ for ballast track and $5.0 \mathrm{~m} / \mathrm{s}^{2}$ for bridges with direct passage and construction elements designed for high-speed traffic. The acceleration limits apply to the vibration frequency band up to $30 \mathrm{~Hz}$ and concern all track maintaining components.

Based on the conducted analysis of the vibration acceleration for the railway embankment, it was found that the maximum values of peak accelerations on the structure of the railway track substructure (railway sleeper) in points $\mathrm{P} 2$ and $\mathrm{P} 3$ amounted to $\mathrm{a}_{\mathrm{x} \text {,max,up }}=0.51$ $\mathrm{m} / \mathrm{s}^{2}, a_{y, \max , \text { up }}=1.22 \mathrm{~m} / \mathrm{s}^{2}, a_{z, \max , u p}=1.45 \mathrm{~m} / \mathrm{s}^{2}$. The obtained acceleration values shall not exceed the limit value $\mathrm{a}_{\mathrm{dop}}=3.5 \mathrm{~m} / \mathrm{s}^{2}$. The condition of providing traffic safety criterion $\mathrm{a}_{\max , \text { TRACK }}<\mathrm{a}_{\mathrm{dop}}$ according to [11] is fulfilled.

The tests proved that there is no need to close the traffic on the analysed line during construction works, causing strong dynamic impact on the railway embankment and railway surface, even when the pile driver was operating directly at the slope of the embankment. Nevertheless, in order to maintain all safety measures, the speed of passing trains was limited at the place of construction works.

\section{References}

1. S. Schneider, S. Marx, Engineering Structures 174, 396 (2018)

2. M.I.Y. Elzain, M. Dafalla, Geotechnical Special Publication 264, 159 (2016)

3. M. Jukowski, J. Bęc, E. Błazik-Borowa, AIP C.P. 1922, 150008 (2018)

4. M. Jukowski, E. Błazik-Borowa, J. Bohatkiewicz, J. Bęc, M. Hypki, 12th FIB International PhDSymposium in Civil Engineering (to be published)

5. E.L. Hajduk, K.C. Bower, T.W. Mays, D.A. Falatok, T.S. Perkins, Geotechnical Special Publication 185, 351 (2009)

6. Executive Project WS-02 PORR (2017) 
7. PN-B-02170: Ocena szkodliwości drgań przekazywanych przez podłoże na budynki (PKN, 2016)

8. K. Stypuła, Doctoral dissertation (1981)

9. R. Ciesielski, Ocena szkodliwości wpływów dynamicznych $w$ budownictwie (PZITB 1973)
10. H. Bachman, W. Amman, Vibration problem in structures. Practical guidelines (1997)

11. Eurocode 0: Basis of structural design+Annex A2 Application for bridges (CEN, 2004) 